\title{
Implementasi Kebijakan Pembangunan Bidang Agama dalam Mewujudkan Kesejahteraan Masyarakat
}

\author{
Yoan Colina \\ Institut Agama Kristen Negeri Palangka Raya \\ collinanyaloh@gmail.com
}

\begin{abstract}
Religion has a strategic role and position whose main function is as an ethical and moral foundation that influences the national development of the Indonesian state. Religion can be said as a value and a system that must be understood and carried out by every community as an individual who lives and resides in a country as the basic foothold to animate the life of the nation and state. In Indonesia, religion is an important milestone in the development of the country because religion is the spiritual, ethical and moral foundation of an individual. The government has a number of policies in the development of the religious sector to support the realization of social welfare. In the public policy stage, program implementation becomes an important stage in the main public policy. To realize social welfare in the community, programs that support development are implemented such as economic, social, infrastructure, and cultural and religious programs. This writing departs from this issue and wants to examine in depth how the implementation of the development program in the field of religion to support the realization of social welfare for the community, especially in the Central Borneo Province, using qualitative descriptive writing methods, using the perspective of Public Administration, Public Policy Theory, Implementation Theory, Development Theory and Community Welfare. The findings of this study indicate that in implementing the development policy in the field of religion, Christian Guidance for the Regional Office of Central Kalimantan province uses three stages of the process, namely input, process and program.
\end{abstract}

Keywords: implementation; development; religion; social welfare

\begin{abstract}
Abstrak
Agama memiliki peran dan kedudukan strategis yang fungsi utamanya adalah sebagai landasan etika dan moral yang mempengaruhi pembangunan nasional negara Indonesia. Agama bisa dikatakan sebagai nilai dan sistem yang harus dipahami serta dijalankan oleh setiap masyarakat sebagai individu yang hidup dan berdiam di suatu negara sebagai pijakan dasar untuk menjiwai kehidupan berbangsa dan bernegara. Di Indonesia agama merupakan tonggak penting dalam pembangunan negara karena agama merupakan landasan spiritual, etika dan moral seorang individu. Pemerintah memiliki sejumlah kebijakan dalam pembangunan bidang agama untuk mendukung terwujudnya kejehteraan sosial. Dalam tahapan kebijakan publik implementasi program menjadi tahapan yang penting dalam pokok kebijakan publik. Untuk mewujudkan kesejahteraan sosial dalam masyarakat, maka diimplementasikan program-program yang menunjang pembangunan seperti program ekonomi, sosial, sarana prasarana, serta budaya dan agama. Penulisan ini berangkat dari isu tersebut dan ingin mengkaji secara mendalam bagaimana implementasi dari program pembangunan bidang agama untuk mendukung terwujudnya kesejahteraan sosial masyarakat, secara khusus di wilayah Provinsi Kalimantan Tengah, dengan menggunakan metode penulisan deskriptif kualitatif, dengan menggunakan perspektif Administrasi Publik, Teori Kebijakan Publik, Teori Implementasi, Teori Pembangunan dan Kesejahteraan Masyarakat. Temuan penelitian ini menunjukkan bahwa dalam mengimplementasikan Kebijakan pembangunan bidang agama, Bimas Kristen Kantor Wilayah provinsi Kalimantan Tengah menggunakan tiga tahapan proses yaitu Input, Proses dan program.
\end{abstract}

Kata Kunci: implementasi; pembangunan; agama; kesejahteraan sosial 


\section{Pendahuluan}

Agama mempunyai peranan dan kedudukan yang penting dan strategis di Indonesia. Fungsi utamanya adalah sebagai landasan moral dan etika yang memengaruhi pembangunan negara. Di sisi ini dapat dilihat bahwa agama dapat dikatakan sebagai sistem dan nilai-nilai yang harus dimengerti dan dijalankan oleh setiap masyarakat sebagai individu yang hidup dan mendiami suatu Negara sebagai pijakan dasar untuk menjiwai kehidupan berbangsa. Sebagaimana yang dikatakan oleh Desi Natalia, Jefry Tarantang, dan I Nyoman Adi Astiti bahwa agama ini pula merupakan kekuatan yang menentukan di dalam seluruh tindak kehidupan bangsa dan perorangan yang didalamnya dijumpai akar dari perasaan dan motif tindakan-tindakan mereka (Natalia et al., 2020). Oleh karena itu, seyogyanya pembangunan di bidang agama perlu mendapat fokus dan perhatian yang baik oleh Pemerintah, baik dari segi program, dan pelaksanaan program, serta pendanaan program agama dalam masyarakat. Program pembangunan di bidang agama dirasa penting mulai dari tingkat pembinaan pendidikan agama dan pelayanan dalam kehidupan beragama, serta toleransi sesama dalam kehidupan beragama.

Ketika berbicara peran agama dalam tulisan ini, kata "agama" yang dirujuk oleh penulis adalah agama dalam pengertian kelembagaan, bukan agama dalam artian dogmatis ataupun doktrinis. Hal ini sangat penting untuk ditekankan, sebagai cara untuk menghindari terdapatnya subjektivitas dalam pemahaman. Saat ini Negara Indonesia sudah mengakui adanya enam agama, yaitu Islam, Kristen, Katolik, Hindu, Budha dan Kong Hu Chu (Natalia, 2019). Dalam kehidupan bernegara keenam agama ini memiliki lembaga masing-masing, yaitu: Majelis Ulama Indonesia (MUI)-Islam, Persekutuan Gereja-Gereja di Indonesia (PGI)-Kristen, Konfrensi Wali Gereja Indonesia (KWI)-Katolik, Parisada Hindu Dharma Indonesia (PHDI)-Hindu, Perwakilan Umat Budha Indonesia (WALUBI)-Budha, , dan Majelis Tinggi Agama Kong Hu Chu Indonesia (MATAKIN)-Kong Hu Chu (Aslati, 2014).

Kebutuhan spiritual merupakan salah satu unsur yang terkandung dalam kesejahteraan sosial (Sadewa et al., 2015), kaitan antara kesejahteraan sosial dan agama, harus dilihat dari berbagai macam sudut pandang dan tidak terlepas dari karakteristik kesejahteraan sosial. Salah satu karakteristik kesejahteraan sosial adalah pentingnya arti seorang manusia, karena dalam usaha kesejahteraan sosial, manusia merupakan subjek maupun objek dari pembangunan itu sendiri. Oleh sebab itu, pembangunan diharapkan mampu mendorong serta menumbuhkan nilai-nilai kemanusiaan, bukan pembangunan yang sifatnya justru malah menghancurkan dan bersifat destruktif. Pembangunan pada hakikatnya dirancang dan dikerjakan oleh manusia, untuk kepentingan umat manusia. Inilah yang dimaksud dengan "manusia sebagai subjek dan objek pembangunan." Manusia merupakan mahluk ciptaan yang paling mulia yang dibekali dengan nurani dan akal yang tidak dimiliki oleh makhluk ciptaan lainnya, manusia mempunyai nilai moral dalam dirinya yang bersumber dari ajaran agama. Nilai moral yang bersumber dari agama inilah yang melandasi pembangunan menuju kesejahteraan sosial untuk kepentingan kemanusiaan. 
Akhir-akhir ini secara nyata dapat dilihat dan dirasakan di beberapa wilayah Indonesia kerap kali muncul permasalahan dan konflik sosial didalam masyarakat yang dipicu oleh isu suku, agama, ras, dan kepentingan antargolongan (SARA)(Akhmadi, 2019), yang tidak hanya dapat mengancam persatuan \& keutuhan negara namun juga berdampak kepada pembangunan Negara. Manusia kehilangan nilai-nilai moral, karena adanya kepentingan, baik itu kepentingan untuk keuntungan pribadi maupun kepentingan golongannya, hal ini menunjukkan bahwa dengan tidak terpenuhinya kebutuhan spiritual akan berdampak pada kesejahteraan sosial.

Kesejahteraan adalah suatu tata kehidupan dan penghidupan sosial, material, maupun spiritual (Sodiq, 2016) yang diliputi rasa keselamatan, kesusilaan dan ketentraman lahir batin yang memungkinkan setiap warga negara untuk mengadakan usaha-usaha pemenuhan kebutuhan jasmani, rohani dan sosial yang sebaik-baiknya bagi diri, rumah tangga serta masyarakat (Euis Sunarti, 2016). Dari sini penulis melihat bahwa bidang agama merupakan salah satu tonggak penting dalam pembangunan dan kemajuan negara. Hal ini tertuang dengan jelas dalam Garis-garis Besar Haluan Negara (GBHN) yang secara khusus telah mengarahkan pembangunan agama dan kepercayaan terhadap Tuhan Yang Maha Esa, pembangunan agama dianggap penting dan menjadi isu yang krusial sejak Indonesia masih berpegang pada GBHN hingga saat ini pun pembangunan bidang agama masih terus di lanjutkan. Pemerintah melalui Kementerian Agama merumuskan program-program dan kebijakan pembangunan bidang agama yang kemudian akan dilaksanakan oleh masing-masing daerah melalui Kantor Wilayah Kementerian Agama Provinsi/Daerah.

Program bidang agama yang baik dan tepat sasaran seharusnya menjadikan individu atau kelompok menjadi lebih baik lagi, sehingga adanya sinergi di dalam praktek sosial. Selaras dengan hal ini Pemerintah melalui Kementerian Agama melaksanakan 8 (delapan) tujuan bidang agama tahun 2020-2024 yang berfokus pada: (1) Peningkatan kualitas kesalehan umat beragama; (2) Penguatan moderasi dan kerukunan umat beragama; (3) Penyediaan layanan keagamaan yang adil dan merata; (4) Peningkatan dan pemberdayaan kelembagaan dan sumber daya ekonomi umat; (5) Perluasan akses pendidikan umum berciri khas agama, pendidikan agama, dan keagamaan; (6) Peningkatan kualitas pengelolaan dan mutu pendidikan agama dan keagamaan; (7) Penguatan produktivitas dan daya saing pendidikan keagamaan; (8) Peningkatan kualitas tata kelola yang efektif dan akuntabel (Kementerian Agama RI, 2020).

Kementerian Agama sebagai lembaga Negara yang mengurusi bidang keagamaan memiliki tugas dan tanggung jawab besar dalam Pembangunan bidang agama, yang menyusun dan melaksanakan segala tahap kebijakan publik bidang Agama. Ada empat kegiatan pokok yang berkenaan dengan kebijakan publik, yaitu: perumusan kebijakan, implementasi kebijakan, evaluasi kebijakan, dan revisi kebijakan, yang merupakan perumusan kembali dari kebijakan (Subarsono, 2005).

Namun yang menjadi pertanyaan dan fokus permasalahan pada kajian ini adalah apakah program pembangunan agama di Indonesia khususnya wilayah Kalimantan Tengah sudah berjalan dengan baik? Apakah program pembangunan agama selaras 
dengan program pemerintah untuk kesejahteraan sosial masyarakatnya? Bagaimana Bimas Kristen Kanwil Kemenag menerjemahkan Implementasi Kebijakan pembangunan bidang agama dalam lingkup wilayah Provinsi Kalimantan Tengah.

Implementasi kebijakan merupakan salah satu tahapan dari proses kebijakan publik. Tahapan implementasi ini merupakan aktivitas yang paling penting karena bagaimanapun baiknya suatu kebijakan, jika tidak dipersiapkan dan direncanakan secara baik dalam implementasinya, maka tujuan kebijakan tidak akan bisa diwujudkan. Dalam memahami realita dan menganalisis implementasi kebijakan diperlukan alat bantu konseptual (conceptual tool) dimana model-model implementasi menjadi alat yang sering dipakai dan bermanfaat bagi keperluan analisis (Orbita Sandyasmoro, 2021).

Berdasarkan latar belakang permasalahan di atas, dapat dipahami bahwa pembangunan bidang agama memiliki hubungan yang erat dengan kesejahteraan sosial masyarakat, dan pemerintah sendiri melalui lembaga terkait telah menyusun programprogram pembangunan keagamaan. Penulis menetapkan yang menjadi rumusan permasalahan dalam kajian tulisan ini adalah bagaimana Implementasi Kebijakan Pembangunan Bidang Agama dalam mewujudkan kesejahteraan masyarakat pada Bimas Kristen di wilayah Provinsi Kalimantan Tengah, dan apa saja faktor-faktor yang dapat mempengaruhi implementasi kebijakan pembangunan bidang agama dalam mewujudkan kesejahteraan masyarakat pada Bimas Kristen di wilayah Provinsi Kalimantan Tengah.

\section{Metode}

Penulisan ini bertujuan untuk memperoleh gambaran deskriptif tentang Implementasi Program Pembangunan Bidang agama dalam mendukung terwujudnya kesejahteraan sosial masyarakat di Wilayah Provinsi Kalimantan Tengah maka jenis penulisan yang digunakan dalam penulisan ini adalah penulisan deskriptif dengan menggunakan pendekatan kualitatif. Penulisan deskriptif kualitatif adalah suatu penulisan yang menggunakan penggambaran atas sebuah fenomena empiris yang menjadi perhatian dalam usaha untuk menguraikan sebuah fenomena secara sistematis, faktual, akurat dan jelas, yang dapat dikaitkan dengan suatu hubungan yang muncul antara gejala satu dan lainnya di dalam kehidupan masyarakat. Uraian gambaran yang dihasilkan dari data deskriptif seperti yang telah diidentifikasikan di atas, didukung pula oleh data lain seperti laporan-laporan dan dokumen-dokumen yang memiliki keterkaitan baik dari kalimat yang kemudian dapat diformulasikan dalam bentuk angka (Moleong, 2016).

\section{Hasil dan Pembahasan}

Dalam Renstra Kementerian Agama 2020-2024 memuat kebijakan-kebijakan yang dirumuskan oleh Kementerian Agama yang merupakan sebuah upaya untuk mencapai visi dan misi Kementerian Agama yang didalamnya terkandung aspirasi dan kebutuhan masyarakat yang bergerak semakin dinamis. Beberapa aspirasi masyarakat tersebut didapatkan dalam serangkaian survei kepuasan masyarakat atas pelayanan yang diberikan oleh Kementerian Agama dalam lima tahun terakhir dan berbagai FGD yang 
diselenggarakan di pusat dan daerah. Kondisi umum, potensi, dan permasalahan yang dihadapi Kementerian Agama pada periode Renstra sebelumnya dijadikan pertimbangan dalam penyusunan Renstra Kementerian Agama periode 2020-2024.

Dalam Visi dan Misi Kementerian Agama periode 2015-2019 tersurat dengan gamblang bahwa Kementerian Agama ingin mewujudkan masyarakat yang sejahtera baik itu secara lahir dan juga batin, yang tertuang dalam visi Kementerian Agama periode 2015-2019, yaitu “Terwujudnya Masyarakat Indonesia yang Taat Beragama, Rukun, Cerdas, dan Sejahtera Lahir Batin dalam Rangka Mewujudkan Indonesia yang Berdaulat, Mandiri, dan Berkepribadian Berlandaskan Gotong Royong". Berdasarkan visi tersebut, maka terlihat bahwa pada periode Renstra Kementerian Agama Tahun 2015-2019, visi pembangunannya terbagi atas empat komponen, yaitu: taat beragama, rukun, cerdas, dan sejahtera.

Dalam upaya mencapai visi tersebut, Kementerian Agama telah menyusun tujuh misi (Periode 2015-2019) yang mendukungnya, yaitu: (1) meningkatkan pemahaman dan pengamalan ajaran agama; (2) memantapkan kerukunan intra dan antarumat beragama; (3) menyediakan pelayanan kehidupan beragama yang merata dan berkualitas; (4) meningkatkan pemanfaatan dan kualitas pengelolaan potensi ekonomi keagamaan; (5) mewujudkan penyelenggaraan ibadah haji dan umrah yang berkualitas dan akuntabel; (6) meningkatkan akses dan kualitas pendidikan umum berciri khas agama, pendidikan agama pada satuan pendidikan umum, dan pendidikan keagamaan; dan (7) mewujudkan tata kelola pemerintahan yang bersih, akuntabel, dan terpercaya.

Visi dan misi tersebut kemudian dijabarkan dalam bentuk tujuan guna memudahkan realisasi dan pencapaiannya, yaitu: (1) peningkatan kualitas pemahaman dan pengamalan ajaran agama; (2) pengukuhan suasana kerukunan hidup umat beragama yang harmonis; (3) pemenuhan kebutuhan akan pelayanan kehidupan beragama yang berkualitas dan merata; (4) peningkatan pemanfaatan dan kualitas pengelolaan potensi ekonomi keagamaan; (5) peningkatan kualitas penyelenggaraan ibadah haji dan umrah; (6) peningkatan kualitas tata kelola pembangunan bidang agama; (7) peningkatan akses pendidikan umum berciri khas agama dan pendidikan keagamaan; dan (8) peningkatan mutu pendidikan umum berciri khas agama, pendidikan agama, dan pendidikan keagamaan (Kementerian Agama RI, 2020).

Pada Periode 2020-2024 Kementerian Agama memiliki Visi dan Misi yang tidak jauh berbeda untuk mewujudkan Masyarakat yang Sejahtera Bimas Kristen Wilayah Provinsi Kalimantan Tengah selaku perpanjangan tangan Pemerintah Pusat di Daerah memiliki tugas dan tanggung jawab untuk mengeksekusi kebijakan tersebut dengan menginterpretasikan kebijakan pemerintah pusat kedalam program-program yang nantinya akan di terapkan, Bimas Kristen Wilayah Provinsi Kalimantan Tengah memiliki Visi yang sejalan yaitu untuk mewujudkan Masyarakat Kristen yang Beriman, Rukun, Cerdas dan Sejahtera Dalam Rangka Menuju Indonesia yang Berdaulat, Mandiri dan Berkepribadian Berlandaskan Gotong Royong. 


\section{Pembahasan}

Implementasi kebijakan pembangunan bidang agama dalam mewujudkan kesejahteraan masyarakat dapat dianalisis dengan menggunakan teori yang diungkapkan oleh Lester dan Stewart (Alamsyah, 2016). Tahapan-tahapan ilmiah impelementasi tersebut adalah sebagai berikut: Agenda setting, Policy formulation, Policy implementation, Policy evaluation, Policy change, dan Policy termination.

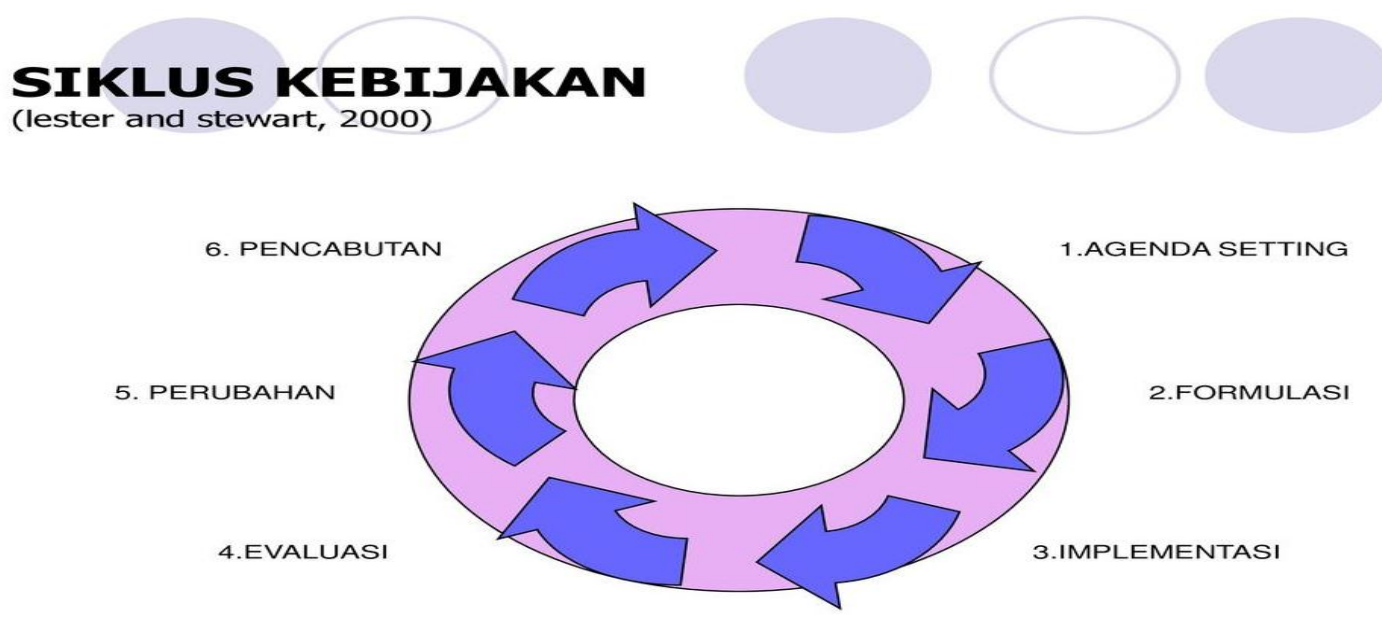

Gambar Siklus Kebijakan (Darmawan \& Nurmandi, 2015)

Dalam proses perumusan program anggaran Bimas Kristen wilayah Provinsi Kalimantan Tengah menggunakan pendekatan Bottom-Up dimana segala program yang dibuat dan diajukan dihimpun terlebih dahulu dari lini bawah, kemudian baru diajukan kepada atasan dan dilanjutkan kepada pusat selaku pemegang kuasa dalam menyetujui anggaran.

Pendekatan bottom-up sendiri menekankan pada pentingnya memperhatikan dua aspek penting dalam implementasi suatu kebijakan (Tachjan, 2006), yaitu: Birokrat pada level bawah (Street Level Bureaucrat), dan kelompok sasaran kebijakan (Target group). Apabila keluaran kebijakan berupa pelayanan kepada kelompok sasaran, maka penting memperhatikan peran street level Bureaucrat karena posisinya sangat terkait dengan kegiatan merealisasikan kebijakan. Langkah-langkah dalam pendekatan bottom-up adalah: pertama, memetakan Stakeholder (actor dan organisasi) yang terlibat dalam implementasi kebijakan pada level terbawah. Kedua, mencari informasi dari para actor tersebut tentang pemahaman mereka terhadap kebijakan yang mereka implementasikan dan apa kepentingan mereka terlibat dalam implementasi. Ketiga, memetakan keterkaitan (jaringan) para actor pada level terbawah tersebut dengan aktor-aktor level diatasnya. Keempat, bergerak ke atas dengan memetakan actor pada level yang lebih tinggi dengan mencari informasi yang sama. Kelima, pemetaan terus dilakukan sampai pada level tertinggi (para Policy maker)(Alamsyah, 2016). 
Data hasil penelitian yang dilakukan, didapati bahwa Bimas Kristen Pada Kanwil Kemenag Provinsi Kalimantan Tengah sudah melakukan langkah-langkah Pendekatan bottom-up dengan melaksanakan Pemetaan stakeholder, mencari informasi dari para aktor, memetakan jaringan Para aktor Pada level terbawah dengan level diatasnya serta melakukan Pemetaan sampai pada level tertinggi atau Policy Maker dengan melalui tiga tahapan proses yaitu input, proses dan program, dengan masing-masing penjelasan sebagai berikut: pertama, input: (a) Membentuk kelompok; (b) Melakukan dialog terbatas dengan kelompok yang sudah dibentuk; (c) Duduk bersama secara internal (antar bimas). Kedua, proses: (1) Merumuskan program; (2) Merumuskan sasaran program; (3) Merumuskan aktor-aktor yang akan digandeng dalam pelaksanaan program; (4) Menyusun RAB. Ketiga, program: (a) Penyuluhan agama; (b) Memberikan pelatihan kepada masyarakat; (c) Memberikan bimbingan keagamaan kepada kelompok yang sudah dibentuk; (d) Menjalin kerjasama dengan sekolah; (e) Melakukan study banding dan mengikuti workshop; (f) Melaksanakan seminar berkerja sama dengan KTB UKM.

\section{Faktor-faktor yang mempengaruhi Implementasi Kebijakan Pembangunan Bidang Agama}

Pandangan terhadap implementasi hanya sebatas problem command and control saja tidak dapat dilepaskan dari paradigma yang digunakan oleh para ahli untuk memahami dan menjelaskan problematika implementasi yang ada. Hal ini terjadi juga pada masyarakat yang belum mengehtaui tentang adanya e-government, adapun yang tahu tetapi hanya sebatas pada pejabat dan pada mereka yang bekerja untuk menutut mengetahui e-government. Ada juga yang tahu tetapi tidak mau menggunakan (Parsaorantua, 2017). Pada kenyataan yang sesungguhnya proses implementasi melibatkan berbagai elemen, seperti: kualitas kebijakan, kapasitas organisasi yang diberi mandat untuk mengimplementasikan kebijakan, kemampuan sumber daya manusia yang ditugaskan untuk mengimplementasikan kebijakan, ketepatan instrumen untuk mencapai tujuan kebijakan, dan lain sebagainya.

Ada 5 (lima) faktor yang mempengaruhi keberhasilan Implementasi menurut Schneider (Purwanto, Erwan Agus; Sulistyastuti, 2012), yaitu: pertama, Viability (Kelangsungan Hidup). Kedua, Theoretical Integrity (Integritas Teori). Ketiga, Scope (Cakupan). Keempat, Capacity (Kapasitas). Kelima, Unintended consequences (Konsekuensi yang tidak diinginkan). Sedangkan menurut Sabatier (Akib, 2010), faktor yang mempengaruhi keberhasilan implementasi adalah sebagai berikut: (1) Tujuan dan sasaran kebijakan yang jelas dan konsisten; (2) Dukungan teori yang kuat dalam merumuskan kebijakan; (3) Proses implementasi memiliki dasar hukum yang jelas sehingga menjamin terjadi kepatuhan para petugas di lapangan dan kelompok sasaran; (4) Komitmen dan keahlian para pelaksana kebijakan; (5) Dukungan para stakeholder; dan (6) Stabilitas kondisi sosial, ekonomi dan politik.

Berdasarkan hasil wawancara dan observasi yang telah dilakukan bersama R. B. Gagat J.W, S.Th selaku Kasie Kelembagaan dan Sistem Informasi Bimbingan Masyarakat Kristen mengungkapkan bahwa ada beberapa faktor yang selama ini menjadi 
penghambat dalam implementasi Kebijakan dan yang kemudian kami jadikan landasan untuk menyusun rencana strategis pembangunan bidang agama dan menerjemahkannya kedalam program-program, antara lain koordinasi, faktor organisasi, komunikasi waktu dan sumber daya baik itu sumber daya manusia, sumber daya organisasi, fasilitas, dan beberapa hal lagi yang nanti bias dicek pada dokumen renstra (R. B. Gagat. J. W., 2020). Dari hasil wawancara tersebut dan dengan mempelajari dokumen Renstra Kementerian Agama dapat disimpulkan bahwa faktor-faktor yang mempengaruhi Implementasi Kebijakan Pembangunan Bidang Agama dalam mewujudkan kesejahteraan masyarakat ada 8 (delapan) hal (Kementerian Agama RI, 2020): (1) Koordinasi; (2) Sikap dan perilaku pihak ketiga/stakeholder; (3) Komunikasi; (4) Faktor organisasi; (5) Waktu dan sumberdaya tidak memadai; (6) Kebijakan tidak didasarkan pada landasan teoritis yang kuat; (7) Hubungan sebab-akibat antara kebijakan dan hasilnya jarang bersifat langsung; (8) Jarang adanya kesepakatan yang bersifat umum diantara para aktor.

Dengan mengacu pada faktor yang dikemukakan oleh Sabatier (dalam Akieb, 2010), yang menjadi faktor keberhasilan implementasi kebijakan adalah tujuan dan sasaran kebijakan yang jelas dan konsisten, dukungan teori yang kuat dalam merumuskan kebijakan, proses implementasi memiliki dasar hukum yang jelas sehingga menjamin terjadi kepatuhan para petugas di lapangan dan kelompok sasaran, komitmen dan keahlian para pelaksana kebijakan, dukungan para stakeholder, stabilitas kondisi sosial, ekonomi dan politik. Kemudian dapat disimpulkan bahwa Bimas Kristen Kanwil Kemenag dalam mengimplementasikan kebijakan pembangunan bidang agama masih belum berhasil dikarenakan faktor penghambat yang ditemukan dalam beberapa poin bertolak belakang dengan yang dikemukakan oleh Sabatier. Kebijakan yang dibuat tidak berdasarkan pada landasan teoritis yang artinya masih yang menjadi tujuan dan sasaran dari kebijakan masih belum jelas dan konsisten dan tidak adanya dukungan teori, kurangnya komitmen dan keahlian para pelaksana kebijakan dan dukungan para stakeholder dan hubungan sebab akibat antara kebijakan dan hasilnya jarang bersifat langsung dan dipengaruhi faktor sosial, ekonomi, dan politik.

\section{Implikasi}

Implementasi kebijakan pembangunan bidang agama dalam mewujudkan Kesejahteraan masyarakat pada Bimas Kristen di wilayah Provinsi Kalimantan Tengah kemudian dilakukan analisa, terhadap input dan proses dari implementasi kebijakan pembangunan bidang agama, dalam hal menghimpun sumber daya dan pengelolaan sumber daya yang dapat dikatakan sudah dilaksanakan. Kemudian perlu menetapkan tujuan dan sasaran yang jelas dari setiap kebijakan yang diambil terkait pembangunan bidang agama. Hal ini perlu kerja sama dengan pihak-pihak terkait dalam mewujudkan kebijakan bidang agama yang membawa kesejahteraan pada masyarakat.

\section{Rekomendasi untuk Penelitian Lanjutan}

Penulis menyadari bahwa penelitian ini masih sangat terbatas sehingga perlu studi dan penelitian lebih lanjut oleh rekan-rekan akademisi baik dosen, mahasiswa dan 
lembaga-lembaga penelitian lainnya khususnya peneliti dalam kajian Ilmu Administrasi publik, Pemerintahan dan Kebijakan Publik untuk dapat melakukan penelitian pada lembaga keagamaan dalam kaitannya terhadap kesejahteraan sosial masyarakat, mengingat "agama" dalam penelitian ini merujuk pada lembaga bukan agama dalam arti doktrinis. Peneliti berharap dengan semakin banyaknya penelitian dalam lingkup kesejahteraan sosial dalam kaitannya dengan agama, akan memperkaya referensi bagi lembaga keagamaan dalam mendukung pencapaian program kesejahteraan sosial umat beragama di Indonesia.

\section{Kesimpulan}

Berdasarkan hasil penelitian dan pembahasan yang dilakukan Bimas Kristen dalam mengimplementasikan kebijakan pembangunan bidang agama dalam mewujudkan kesejahteraan sosial masyarakat di wilayah provinsi Kalimantan Tengah adalah melalui tiga tahapan proses. Pertama, Input yaitu membentuk kelompok, melakukan dialog terbatas dengan kelompok yang telah dibentuk dan duduk bersama secara internal antar Bimas Agama. Kedua Proses yaitu merumuskan program, merumuskan sasaran program, merumuskan aktor-aktor yang akan digandeng dalam pelaksanaan program dan menyusun RAB. Ketiga, program (penyuluhan agama, memberikan pelatihan kepada masyarakat, bimbingan keagamaan kepada kelompok yang sudah dibentuk, menjalin kerjasama dengan sekolah, melakukan study banding dan mengikuti workshop dan seminar berkerja sama dengan KTB UKM. Dari tahapan-tahapan tersebut, dapat disimpulkan bahwa Bimas Kristen melakukan pendekatan bottom-up dengan melakukan pemetaan Stakeholder, menemukan informasi dari para aktor, memrepresentasikan jaringan para aktor pada level terbawah dengan level di atasnya, serta melakukan pemetaan hingga tahap yang paling tinggi atau Policy Maker. Namun dalam mengimplementasikan kebijakan pembangunan bidang agama masih belum dikatakan berhasil dikarenakan faktor penghambat yang ditemukan dalam beberapa poin bertolak belakang dengan yang dikemukakan oleh Sabatier. Kebijakan yang dibuat tidak berdasarkan pada landasan teoritis yang artinya masih yang menjadi tujuan dan sasaran dari kebijakan masih belum jelas dan konsisten dan tidak adanya dukungan teori, kurangnya komitmen dan keahlian para pelaksana kebijakan dan dukungan para stakeholder dan hubungan sebab akibat antara kebijakan dan hasilnya jarang bersifat langsung dan dipengaruhi faktor sosial, ekonomi dan politik

\section{Rujukan}

Akhmadi, A. (2019). Moderasi Beragama Dalam Keragaman Indonesia Religious Moderation in Indonesia' S Diversity. Jurnal Diklat Keagamaan, 13(2), 45-55.

Akib, H. (2010). Implementasi Kebijakan : Apa, mengapa Bagimana. Jurnal Adminstrasi Publik, 1(1), 1-11. https://media.neliti.com/media/publications/97794-IDimplementasi-kebijakan-apa-mengapa-dan-b.pdf

Alamsyah, K. (2016). Kebijakan Publik Konsep dan Aplikasi. Kebijakan Publik Konsep Dan Aplikasi, 5-10. http://repository.unpas.ac.id/42249/3/Buku Kebijakan Publik REV 15 nov.pdf 
Aslati, A. (2014). Optimalisasi Peran Fkub Dalam Menciptakan Toleransi Beragama Di Kota Pekanbaru. Toleransi, 6(2), 188-199. https://doi.org/10.24014/trs.v6i2.906

Darmawan, E., \& Nurmandi, A. (2015). Agenda Setting dalam Perencanaan Pembangunan Perbatasan di Kepri Tahun 2015. Journal of Governance and Public Policy, 2(3). https://doi.org/10.18196/jgpp.2014.0042

Euis Sunarti. (2016). Indikator Keluarga Sejahtera. Angewandte Chemie International Edition, 6(11), 951-952., 5-24.

Kementerian Agama RI. (2020). Rencana Strategis Kementerian Agama Tahun 20202024. 1-309.

https://bali.kemenag.go.id/uploads/media/2020/07/RENSTRA_KEMENAG_202 0-2024.pdf

Moleong, L. J. (2016). Metodologi Penelitian Kualitatif. Remaja Rosdakarya.

Natalia, D. (2019). Prosiding Seminar Nasional Institut Agama Hindu Negeri Tampung Penyang Palangka Raya http://prosiding.iahntp.ac.id. 2(September 2019), 12-20.

Natalia, D., Tarantang, J., \& Astiti, N. N. A. (2020). Makna Manuhir Dalam Kehidupan Masyarakat Dayak Ngaju Di Kota Palangka Raya. Jurnal Studi Agama Dan Masyarakat, 16(1), 24-34. https://doi.org/10.23971/jsam.v16i1.2077

Orbita Sandyasmoro, T. (2021). Hubungan Implementasi Kebijakan Transaksi Non Tunai dengan Fraud. 7(2), 149-157.

Parsaorantua, P. H. (2017). ImPlementasi Teknologi Informasi dan Komunikasi. VI(3).

Purwanto, Erwan Agus; Sulistyastuti, D. R. (2012). ImPlementasi Kebijakan Publik (1st ed.). Gava Media.

Sadewa, M., Budiman, M., \& Rijani, M. (2015). Hubungan antara \{Religiusitas\} dan Kesejahteraan pada Masyarakat Banjar, Kalimantan Selatan. At-Taradhi; Jurnal Studi Ekonomi, 6(December 2015), 207-217.

Sodiq, A. (2016). Konsep Kesejahteraan Dalam Islam. Equilibrium, 3(2), 380-405. http://journal.stainkudus.ac.id/index.php/equilibrium/article/view/1268/1127

Subarsono, A. (2005). Analisis kebijakan publik : konsep, teori dan aplikasi. Pustaka Pelajar.

Tachjan, H. (2006). ImPlementasi Kebijakan Publik (D. M. dan C. Paskarina (ed.)). AIPI Bandung. 